\title{
Review \\ Roles of the C-Terminal Amino Acids of Non-Hexameric Helicases: Insights from Escherichia coli UvrD
}

\author{
Hiroaki Yokota (D) \\ Biophotonics Laboratory, The Graduate School for the Creation of New Photonics Industries, 1955-1, \\ Kurematsu-cho, Nishi-ku, Hamamatsu, Shizuoka 431-1202, Japan; yokota@gpi.ac.jp
}

check for updates

Citation: Yokota, H. Roles of the C-Terminal Amino Acids of Non-Hexameric Helicases: Insights from Escherichia coli UvrD. Int. J. Mol. Sci. 2021, 22, 1018. https://doi.org/ 10.3390/ijms22031018

Received: 23 December 2020

Accepted: 18 January 2021

Published: 20 January 2021

Publisher's Note: MDPI stays neutral with regard to jurisdictional claims in published maps and institutional affiliations.

Copyright: (C) 2021 by the author. Licensee MDPI, Basel, Switzerland. This article is an open access article distributed under the terms and conditions of the Creative Commons Attribution (CC BY) license (https:// creativecommons.org/licenses/by/ $4.0 /)$.

\begin{abstract}
Helicases are nucleic acid-unwinding enzymes that are involved in the maintenance of genome integrity. Several parts of the amino acid sequences of helicases are very similar, and these quite well-conserved amino acid sequences are termed "helicase motifs". Previous studies by $\mathrm{X}$-ray crystallography and single-molecule measurements have suggested a common underlying mechanism for their function. These studies indicate the role of the helicase motifs in unwinding nucleic acids. In contrast, the sequence and length of the C-terminal amino acids of helicases are highly variable. In this paper, I review past and recent studies that proposed helicase mechanisms and studies that investigated the roles of the C-terminal amino acids on helicase and dimerization activities, primarily on the non-hexermeric Escherichia coli (E. coli) UvrD helicase. Then, I center on my recent study of single-molecule direct visualization of a UvrD mutant lacking the C-terminal 40 amino acids (UvrD $\Delta 40 \mathrm{C}$ ) used in studies proposing the monomer helicase model. The study demonstrated that multiple UvrD $\triangle 40 \mathrm{C}$ molecules jointly participated in DNA unwinding, presumably by forming an oligomer. Thus, the single-molecule observation addressed how the C-terminal amino acids affect the number of helicases bound to DNA, oligomerization, and unwinding activity, which can be applied to other helicases.
\end{abstract}

Keywords: protein-nucleic acid interactions; helicase; single-molecule fluorescence imaging; Cterminal amino acids; protein assemblies; enzyme function

\section{Introduction}

Helicases are enzymes that unwind nucleic acids using energy derived from NTP hydrolysis and fulfill essential functions in the maintenance of genome integrity, including DNA replication, repair, and recombination. Several parts of the amino acid sequences of helicases are very similar, and these quite well-conserved amino acid sequences are termed the "helicase motifs" [1]. These motifs allow us to classify helicases into six superfamilies (SFs). The number of conserved helicase motifs for SF1 and SF2 is at least seven, and they share common sequences [2]. These conserved motifs, which are essential to adenosine triphosphate (ATP) hydrolysis and nucleic acid binding and unwinding, are commonly placed not at $\mathrm{N}$ - and $\mathrm{C}$-termini, but in the middle of the amino acid sequences. In contrast, the sequence and length of the N-terminal and C-terminal amino acids of helicases are highly variable [3], though these terminal regions are in charge of various protein functions.

The six SFs can be categorized by the number of molecules that are involved in helicase functions. SF3-6 helicases function through the formation of a hexameric ring around DNA [4,5], while SF1 and SF2 helicases function in a non-hexameric form.

Tertiary structures resolved by X-ray crystallography [6-9] indicate that SF1 helicases share four structural domains (1A, 1B, 2A, and 2B) and function using a common mechanism. However, two conflicting DNA-unwinding models, dimeric-helicase and monomeric-helicase models have been proposed for non-hexameric helicases.

The N-terminal and C-terminal amino acids of helicases, which are not conserved in SF1 and SF2, serve various protein functions. In particular, many studies demonstrated 
that the C-terminus of helicases plays essential roles in nucleic acid binding and dimerization activities.

In this paper, I review past and recent studies that proposed helicase mechanisms and studies that investigated the roles of the C-terminal amino acids of helicase and dimerization activities, primarily on the non-hexermeric Escherichia coli (E. coli) SF1 UvrD helicase. I center on my recent study of single-molecule direct visualization of a UvrD mutant lacking the C-terminal 40 amino acids (UvrD $\Delta 40 \mathrm{C})$ [10] used in studies proposing the monomer helicase model. The study demonstrates that two or three UvrD $\triangle 40 \mathrm{C}$ molecules jointly participate in DNA unwinding, presumably by forming an oligomer, similar to that of wild-type UvrD. Thus, the results should settle the controversy of the monomer/oligomer helicase models, address the role of C-terminal amino acids in binding and unwinding DNA, and elucidate their effects on helicase and dimerization activities.

\section{Helicase Superfamily}

The sequence similarity of the helicase motifs among helicases allows us to classify helicases into six superfamilies (SF1-6). The six SFs can be categorized by the number of molecules that are involved in helicase function. SF3-6 helicases function through the formation of a hexameric ring around DNA [4,5], whereas SF1 and SF2 helicases function in a non-hexameric form.

Non-hexameric SF1 and SF2 helicases consist of at least seven conserved amino acid motifs, "helicase motifs" (I, Ia, II, III, IV, V, and VI) [1,11]. The seven conserved motifs are partially varied between SF1 and SF2. For example, the primary structures and locations of helicase motif III in SF1 and SF2 helicases are not homologous.

\subsection{Superfamily 1 Helicases}

Superfamily 1 is a major class of helicases that are essentially involved in nucleid acid metabolism [3,12]. Some of the well-studied SF1 helicases are E. coli UvrD and Rep, and Bacillus stearothermophilus (B. stearothermophilus) or Geobacillus stearothermophilus (G. stearothermophilus) PcrA, whose primary structures are highly homologous (approximately $40 \%$ ), and these have been resolved by $X$-ray crystallography [6-9]. These structures revealed that these three SF1 helicases contain four structural domains $(1 \mathrm{~A}, 1 \mathrm{~B}, 2 \mathrm{~A}$, and 2B). Their structures, resolved by $\mathrm{X}$-ray crystallography, are shown in Figure $1 \mathrm{~A}-\mathrm{C}$. The structural similarity is seen from the structural superposition of UvrD and PcrA (Rep) (Figure 1D,E). Figure 2 shows the results obtained by the secondary structure-based sequence alignment of UvrD, PcrA, and Rep. The I, Ia, II, III, IV, V, and VI helicase motifs [6] as well as the 1A, 1B, 2A, and 2B domains and unstructured C-terminus of UvrD are indicated. 


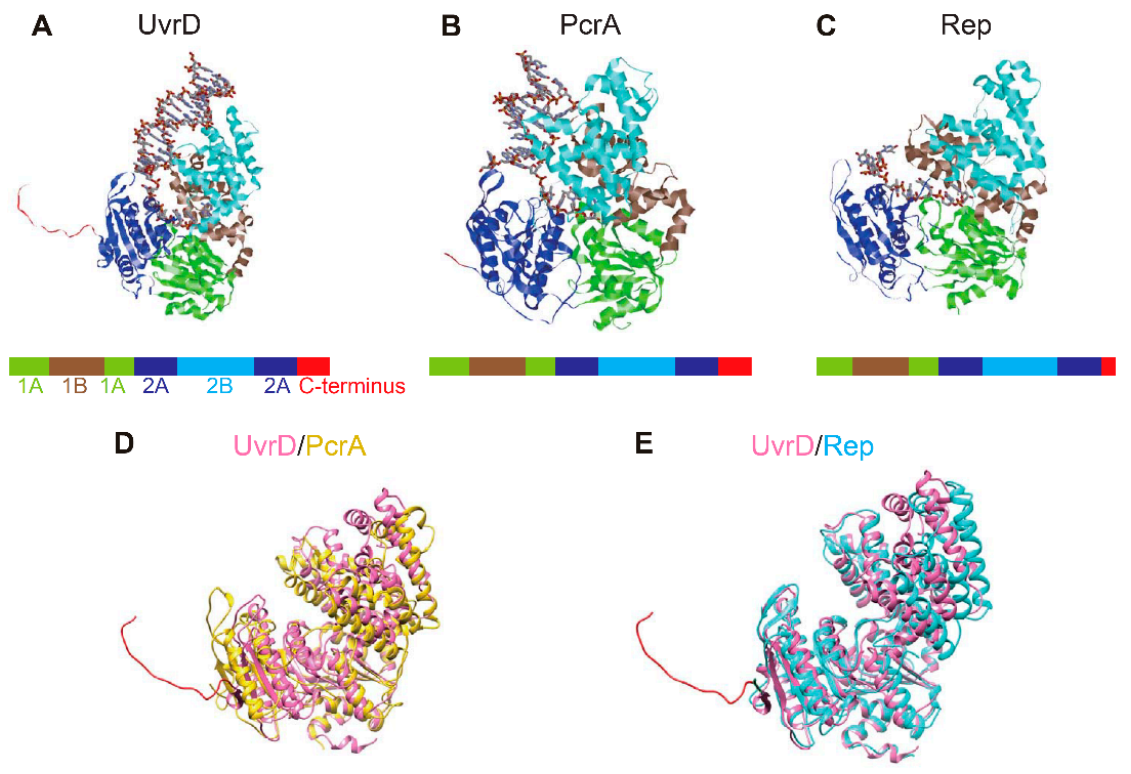

Figure 1. Structural similarity among SF1 helicases. (A-C) Crystal structures of Escherichia coli (E. coli) UvrD (PDB code 2IS4) (A), Geobacillus stearothermophilus (G. stearothermophilus) PcrA (PDB code 3PJR) (B), and E. coli Rep (PDB code 1UAA) (C), which were complexed with DNA. The 1A, 1B, $2 \mathrm{~A}$, and $2 \mathrm{~B}$ domains and unstructured C-terminus are colored in blue, brown, cyan, green, and red, respectively. Each primary structure diagram is depicted below the tertiary structure. (D,E) Structural superposition of UvrD and PcrA (D), and UvrD and Rep (E). The unstructured C-termini of UvrD and PcrA are colored in red and blue, respectively. Molecular graphics and analyses performed with UCSF Chimera, developed by the Resource for Biocomputing, Visualization, and Informatics at the University of California, San Francisco, with support from NIH P41-GM103311 [13].

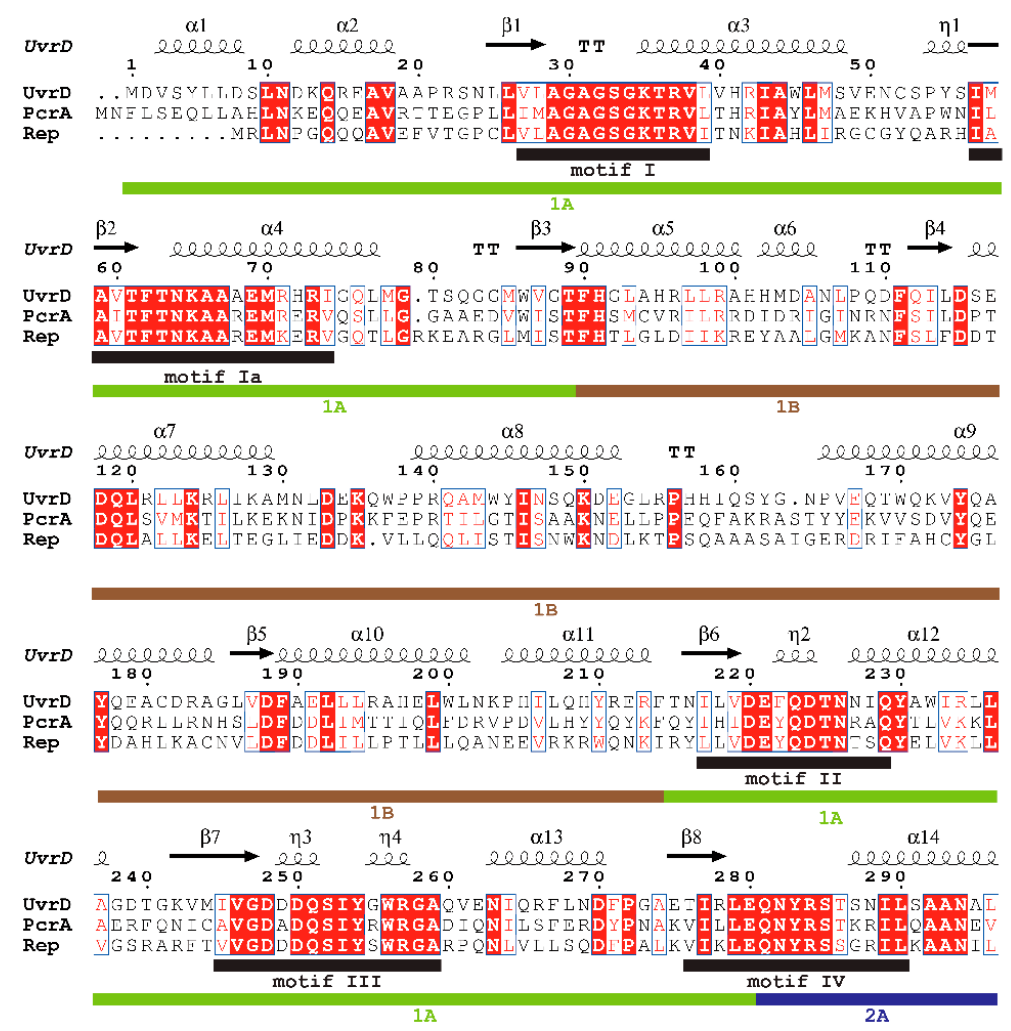

Figure 2. Cont. 


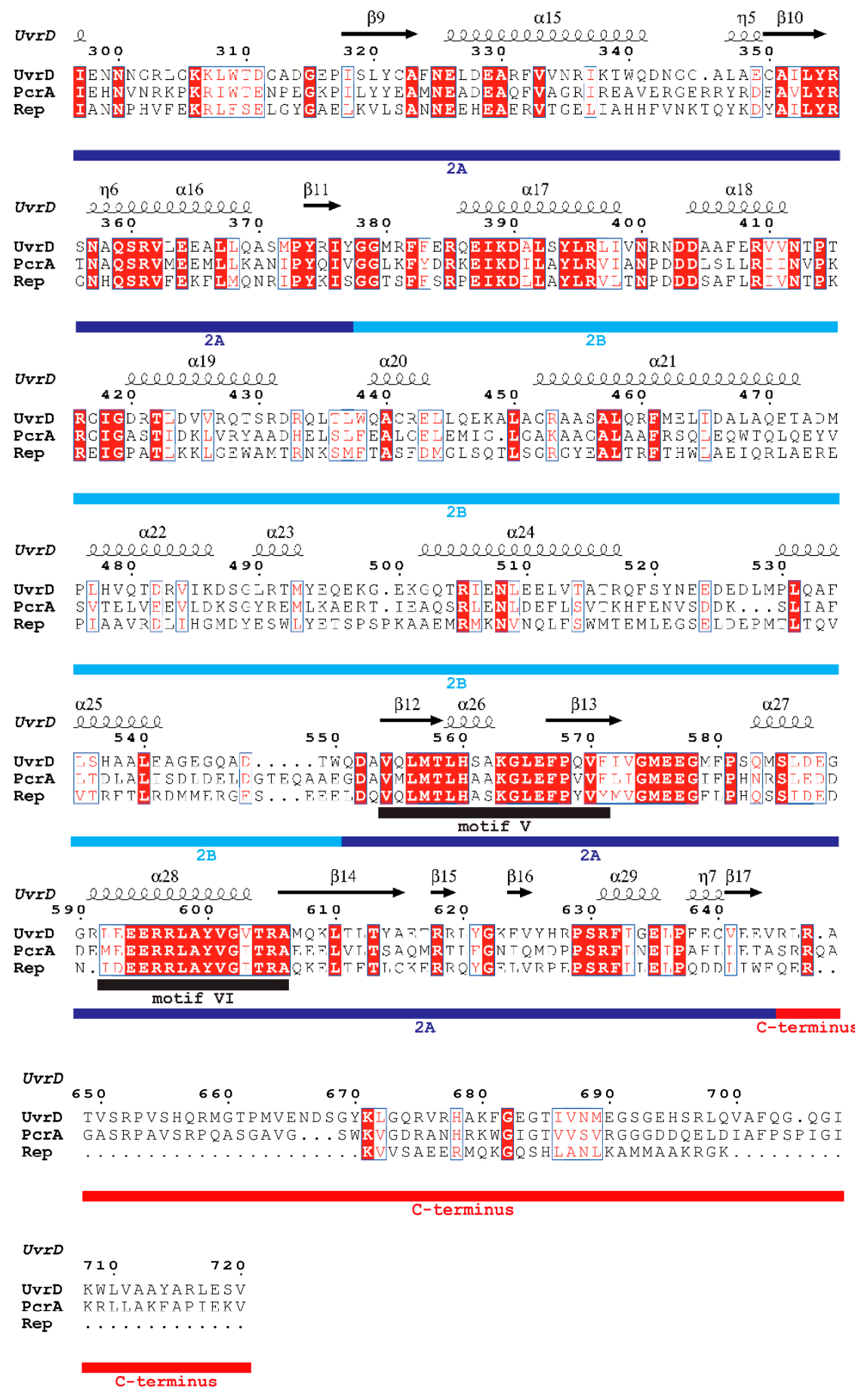

Figure 2. Secondary structure-based sequence alignment of SF1 helicases. The alignment and color representation were performed using ClustalW2.1 (https: / / www.genome.jp/tools-bin/clustalw) [14] and ESPript 3.0 web-based server (http:/ / espript.ibcp.fr/ESPript/ESPript/) [15], respectively. All of the conserved residues are boxed with blue frames, and the fully conserved residues are colored white with a red background, whereas the less conserved residues are colored red. Helices and strands are labeled according to the UvrD structure. $\alpha$-helices, 310 -helices, and $\pi$-helices are indicated as medium, small, and large squiggles, respectively. $\beta$-strands are displayed as arrows, strict $\beta$-turns as TT letters, and strict $\alpha$-turns as TTT. The I, Ia, II, III, IV, V, and VI helicase motifs [6] as well as the $1 \mathrm{~A}, 1 \mathrm{~B}, 2 \mathrm{~A}$, and $2 \mathrm{~B}$ domains and unstructured C-terminus of $\mathrm{UvrD}$, are indicated. 


\subsection{Superfamily 2 Helicases}

The SF2 is another main superfamily including various DNA helicases as well as several subfamilies of RNA helicases. Most RNA helicases are categorized as SF2 and are members of the Asp-Glu-Ala-Asp (DEAD)-box, the Asp-Glu-Ala-His (DEAH), and the DExH (where $x$ can be any amino acid) subfamilies. The four-letter names of the subfamilies come from the sequence of helicase motif II.

\subsection{Proposed Models for the Functional Unit of Some SF1 and SF2 Helicases}

Although non-hexameric SF1 and SF2 helicases have common amino acid motifs, the opposing dimeric-helicase and monomeric-helicase models have been proposed for non-hexameric SF1 and SF2 helicases. On one hand, the dimeric-helicase model has been proposed for SF1 helicases (E. coli UvrD [10,16-21], Rep [8,22,23], and TraI [24] helicases, and B. subtilis PcrA [25] helicase) and SF2 helicases (E. coli RecQ [26], hepatitis C viral NS3 [27], and DEAD-box RNA helicases, including E. coli CsdA [28] and RhlB [29], G. stearothermophilus CshA [30], a and Thermus thermophilus (T. thermophilus) Hera [31]). On the other hand, the monomeric-helicase model was proposed for SF1 UvrD [6,32], PcrA [9,33], TraI [34], phage T4 Dda [35,36], and SF2 RecQ [37-39] and NS3 helicases [40]. Table 1 lists the cellular functions of some SF1 and SF2 helicases and the proposed models for their functional units.

Table 1. Cellular functions of some SF1 and SF2 helicases and the proposed models of their functional units.

\begin{tabular}{|c|c|c|c|c|c|}
\hline SF & Helicase & Organism & Cellular Functions & $\begin{array}{l}\text { Proposed Models for } \\
\text { Functional Unit }\end{array}$ & References \\
\hline SF1 & UvrD & E. coli & DNA repair & Monomer/Dimer & {$[6,10,16-21,32]$} \\
\hline SF1 & Rep & E. coli & DNA replication & Dimer & {$[8,22,23]$} \\
\hline SF1 & TraI & E. coli & $\begin{array}{l}\text { DNA transfer during } \\
\text { conjugation }\end{array}$ & Monomer/Dimer & {$[24,34]$} \\
\hline SF1 & PcrA & B. subtilis & $\begin{array}{l}\text { DNA repair } \\
\text { Rolling replication of } \\
\text { plasmids }\end{array}$ & Monomer/Dimer & {$[9,25,33]$} \\
\hline SF1 & Dda & Phage T4 & $\begin{array}{l}\text { DNA replication } \\
\text { initiation } \\
\text { DNA recombination }\end{array}$ & Monomer & {$[35,36]$} \\
\hline SF2 & RecQ & E. coli & DNA recombination & Monomer/Dimer & {$[26,37-39]$} \\
\hline SF2 & $\operatorname{Csd} \bar{A}$ & E. coli & Ribosome biogenesis & Dimer & [28] \\
\hline SF2 & RhlB & E. coli & RNA metabolism & Dimer & [29] \\
\hline SF2 & NS3 & Hepatitis $C$ virus & Viral DNA replication & Monomer/Dimer & {$[27,40]$} \\
\hline SF2 & CshA & $\begin{array}{c}\text { G. } \\
\text { stearothermophilus }\end{array}$ & RNA metabolism & Dimer & [30] \\
\hline SF2 & Hera & T. thermophilus & RNA metabolism & Dimer & [31] \\
\hline
\end{tabular}

The dimeric-helicase and monomeric-helicase models have been proposed mostly by structural and biochemical studies, including X-ray crystallography, ATPase assays, stopped-flow method-based single- and multiple-turnover DNA-unwinding assays, size exclusion chromatography, and analytical ultracentrifugation. The models for some helicases were tested by single-molecule measurements as this paper illustrates for SF1 UvrD helicase in the following sections. Note that the solution conditions, such as $\mathrm{NaCl}$ concentration, $\mathrm{pH}$, glycerol concentration, and temperature, affect the self-assembly of helicases. For UvrD helicase, Maluf et al. extensively investigated the effects of such solution conditions on the self-assembly states. They quantitively characterized the self-assembly equilibria of wild-type $\mathrm{UvrD}$ as a function of $\mathrm{NaCl}$ and glycerol concentrations as well astemperature using analytical ultracentrifugation and concluded that a lower $\mathrm{NaCl}$ concentration, a lower $\mathrm{pH}$, a lower glycerol concentration, and a higher temperature were favorable for UvrD oligomer formation [41]. 


\subsection{Dimeric-Helicase and Monomeric-Helicase Models for SF1 and SF2 Helicases Other than E. coli SF1 UvrD Helicase}

This paper focuses on E. coli SF1 UvrD helicase and describes studies that proposed dimeric-helicase and monomeric-helicase models for UvrD helicase. For the sake of comparison and better understanding, this section deals with B. subtilis SF1 PcrA and E. coli SF2 RecQ helicases, for which both dimeric-helicase and monomeric-helicase models have been proposed, and provides a brief overview of the studies that proposed the models.

\subsubsection{PcrA}

For SF1 PcrA helicase, a monomeric helicase model was proposed based on the obtained crystal structures of monomeric PcrA-DNA complexes, with the result that only the fraction of PcrA monomer was detected by size-exclusion chromatography [9]. On the other hand, Yang et al. indicated that PcrA functions as a dimeric form through single- and multiple-turnover DNA-unwinding experiments [25]. They showed that DNA unwinding by PcrA was promoted by increasing the PcrA concentration and that the Hill coefficient in unwinding and ATPase reactions was about 2. Niedziela-Majka et al. showed through single-turnover DNA-unwinding experiments that PcrA monomers exhibited excellent single-stranded DNA (ssDNA) translocase activity but no detectable helicase activity [42]. In contrast, Chistry et al. suggested by single-molecule measurements that PcrA monomer can unwind double-stranded DNA (dsDNA) of more than 1 kbase pair (bp) length in the presence of its partner protein RepD [33].

\subsection{2. $\operatorname{Rec} Q$}

For SF2 RecQ helicase, $\mathrm{Xu}$ et al. indicated that the helicase unwinds DNA in monomeric form [37]. They reached this conclusion from the following results: (i) immunoprecipitation experiments detected no interaction between RecQ monomers; (ii) size exclusion chromatography and analytical-sedimentation-equilibrium-ultracentrifugation experiments suggested that RecQ helicase exists as a monomer in solution; and (iii) stopped-flow experiments detected no increase in the DNA unwinding rate with the increase in RecQ helicase concentration. Li et al. performed fluorescence cross-correlation spectroscopy (FCCS) and reported that a RecQ monomer was capable of unwinding short DNA substrates, which supports the monomeric model [39]. They also reported that multiple RecQ monomers simultaneously could bind to long DNA substrates and suggested that these RecQ monomers unwound the DNA quite efficiently using "functional cooperativity". They then concluded that the length of DNA substrates, the number and length of the $3^{\prime}$ ssDNA tail, and the temperature affect the functional cooperativity. This DNA length effect coincided with the results using single-molecule fluorescence imaging reported by Rad et al. [26]. They used $\lambda$ DNA (48.5 kbp) and revealed that the unwinding rate of RecQ increased with the increase in RecQ concentration, which was different from the results reported by $\mathrm{Xu}$ et al. using short DNA substrates and suggested that a RecQ dimer was responsible for the initiation of DNA unwinding.

\section{C-Terminal Amino Acids}

The seven helicase motifs of SF1 and SF2 helicases, which are essential to ATP hydrolysis and nucleic acid binding and unwinding, are commonly placed in the middle of the amino acid sequences. In contrast, the $\mathrm{N}$-terminal and $\mathrm{C}$-terminal amino acids outside of helicase motifs exhibit large variations in their sequence and length, though these terminal regions are in charge of various protein functions.

Past studies showed that the C-terminus is crucial to nucleic acid binding and unwinding and dimer formation. These include the bacteriophage P4 gp $\alpha$ helicase-primase, the yeast Rad25 helicase [43,44], and Werner's syndrome protein $[45,46]$. The roles of the C-terminus have been well studied for SF2 DEAD-box RNA helicases that are engaged in RNA metabolism [47]. For example, the C-terminal region of CshA and Hera served 
dual functions of dimerization and RNA binding [30,31]. Table 2 lists the reported roles of C-terminal amino acids on SF2 DEAD/DEAH-box RNA helicases.

Table 2. Reported roles of C-terminal amino acids on SF2 Asp-Glu-Ala-Asp (DEAD)/Asp-Glu-AlaHis (DEAH) box RNA helicases.

\begin{tabular}{|c|c|c|c|c|}
\hline Subfamily & Helicase & Organism & $\begin{array}{c}\text { Roles of C-Terminal Amino } \\
\text { Acids }\end{array}$ & References \\
\hline DEAD-box & CsdA & E. coli & RNA binding & [28] \\
\hline DEAD-box & CshA & G. stearothermophilus & $\begin{array}{l}\text { RNA binding, RNA-dependent } \\
\text { ATP hydrolysis, and interaction } \\
\text { with degradosome }\end{array}$ & {$[30,48]$} \\
\hline DEAD-box & Hera & T. thermophilus & RNA binding and dimerization & [31] \\
\hline DEAD-box & Mss116p & S. cerevisae & RNA-dependent ATPases & [49] \\
\hline DEAD-box & YxiN & B. subtilis & RNA binding & [50] \\
\hline DEAD-box & p68 & Homo sapiens & RNA binding & [51] \\
\hline
\end{tabular}

\section{C-Terminus Truncated UvrD}

E. coli SF1 UvrD helicase (720 amino acids) assumes a pivotal role in both nucleotideexcision repair and methyl-directed mismatch repair [52]. Like other SF1 helicases, UvrD consists of four structural domains $(1 \mathrm{~A}, 1 \mathrm{~B}, 2 \mathrm{~A}$, and 2B) [6] and has an unstructured Cterminal region (645-720 amino acids) [6,53]. The UvrD protein is a $3^{\prime}$ to $5^{\prime}$ helicase and unwinds dsDNA from the $3^{\prime}$ end ssDNA tail using energy derived from ATP hydrolysis. Past biochemical studies have indicated that this helicase exhibits optimal DNA unwinding activity in its oligomeric form [16].

However, X-ray crystallographic structures of monomeric UvrD [6] and results from genetic and biochemical assays provided the opposite monomeric-helicase model [32,54]. In these studies, UvrD $\triangle 40 \mathrm{C}$ was used. Mechanic et al. found, via genetic-complementation assays using a strain lacking the $u v r D$ gene, that $\mathrm{UvrD} \Delta 40 \mathrm{C}$ was competent enough to fulfill methyl-directed mismatch repair and nucleotide-excision repair. They also examined self-interaction between $\operatorname{UvrD} \triangle 40 \mathrm{C}$ molecules with a yeast two-hybrid system and reported that $\mathrm{UvrD} \triangle 40 \mathrm{C}$ was unable to dimerize. In addition, they found that $\mathrm{UvrD} \Delta 40 \mathrm{C}$ retained comparable ssDNA-binding, ssDNA-stimulated ATPase, and DNA-unwinding activities, compared to wild-type UvrD. They reported the following results: (i) the affinity of ATP to UvrD $\triangle 40 \mathrm{C}\left(K_{m}=62 \mu \mathrm{M}\right)$ was almost as same as that to wild-type UvrD $\left(K_{m}=50 \mu \mathrm{M}\right)$; (ii) the turnover rate for ssDNA-stimulated ATP hydrolysis for $\operatorname{UvrD} \Delta 40 \mathrm{C}$ $\left(k_{\mathrm{cat}}=147 \mathrm{~s}^{-1}\right)$ was almost the same as that for wild-type $\operatorname{UvrD}\left(k_{\mathrm{cat}}=157 \mathrm{~s}^{-1}\right)$; and (iii) UvrD $\triangle 40 \mathrm{C}$ unwound 92-bp and 234-bp partial duplex DNA substrates as efficiently as wild-type UvrD. They also indicated that UvrD $\triangle 40 \mathrm{C}$ could not dimerize in their results (obtained by size-exclusion chromatography and analytical-sedimentation-equilibriumultracentrifugation experiments). The elution pattern of UvrD $\triangle 40 \mathrm{C}$ in size-exclusion chromatography showed only a single peak that corresponded to the $\mathrm{UvrD} \triangle 40 \mathrm{C}$ monomer. Molecular mass that corresponded to dimeric $\mathrm{UvrD} \Delta 40 \mathrm{C}$ was not detected in analyticalsedimentation-equilibrium-ultracentrifugation experiments even though the UvrD $\triangle 40 \mathrm{C}$ concentration was increased. Therefore, they proposed the monomeric model. Table 3 lists the reported effects of deleting C-terminal amino acids from UvrD in its oligomerization state.

Table 3. Effects of deleting C-terminal amino acids from UvrD on its oligomerization state.

\begin{tabular}{cccc}
\hline UvrD & $\begin{array}{c}\text { Size-Exclusion } \\
\text { Chromatography }\end{array}$ & $\begin{array}{c}\text { Sedimentation Equilibrium } \\
\text { Experiments }\end{array}$ & $\begin{array}{c}\text { Velocity Equilibrium } \\
\text { Experiments }\end{array}$ \\
\hline UvrD $\Delta 40 \mathrm{C}$ & Monomer [32] & Monomer [32] & Monomer [32] \\
UvrD $\Delta 73 C$ & N.D. & Dimer [41] & N.D. \\
\hline
\end{tabular}


UvrD mutants lacking longer C-terminal amino acids (UvrD $\Delta 73 \mathrm{C}$, UvrD $\Delta 102 \mathrm{C}$, or UvrD $\Delta 107 \mathrm{C})$ were also studied [32,53,54]. UvrD $\Delta 102 \mathrm{C}$ and UvrD $\Delta 107 \mathrm{C}$ were incompetent and could not perform DNA repair. UvrD $\Delta 73 C$ exhibited a slightly reduced ssDNA binding affinity, whereas UvrD $\triangle 102 C$ displayed a considerably reduced affinity. The ssDNA-binding affinity of the C-terminal deletion mutants corresponded with their ATPase and DNA-unwinding abilities. UvrD $\Delta 73 \mathrm{C}$ kept its abilities, but $\mathrm{UvrD} \Delta 102 \mathrm{C}$ did not. They reported the following results: (i) the ssDNA binding affinity of $\operatorname{UvrD} \Delta 73 \mathrm{C}\left(K_{m}=2.5 \mu \mathrm{M}\right)$ was more than four times lower than that of wild-type $\operatorname{UvrD}\left(K_{m}=0.54 \mu \mathrm{M}\right)$; (ii) the turnover rate for the ssDNA-stimulated ATP hydrolysis for $\operatorname{UvDD} \Delta 73 \mathrm{C}\left(k_{\mathrm{cat}} \sim 500 \mathrm{~s}^{-1}\right)$ was almost the same as that for wild-type $\operatorname{UvrD}\left(k_{\text {cat }} \sim 400 \mathrm{~s}^{-1}\right)$. The $\operatorname{UvrD} \Delta 102 \mathrm{C}$ mutant was void of both the unstructured C-terminus (645-720 amino acid) and some of the 2A domain [6]. Thus, the unstructured C-terminal region is supposed to be the necessity for DNA unwinding, and the conserved 2A domain should be more important for activity. Then, it is probable that the length of the unstructured C-terminal region affects the DNAunwinding ability. Maluf et al. described the potential for UvrD $\triangle 40 \mathrm{C}$ to dimerize, as they illustrated that $\mathrm{UvrD} \Delta 73 \mathrm{C}$ was able to dimerize [41]. They showed that $\mathrm{UvrD} \Delta 73 \mathrm{C}$ did dimerize by analytical-sedimentation-equilibrium-ultracentrifugation experiments, but the dimerization equilibrium constant was 25 times smaller than that for wild-type UvrD. Table 4 summarizes the reported effects of deleting C-terminal amino acids from UvrD on its functions.

Table 4. Effects of deleting C-terminal amino acids from UvrD on its functions.

\begin{tabular}{ccccc}
\hline UvrD & DNA Repair & DNA-Stimulated & DNA Binding & DNA Unwinding \\
\hline UvrD $\Delta 40 C$ & $+{ }^{1}[32,54]$ & $+[32,54]$ & $+[54]$ & $+[32,54]$ \\
UvrD $\Delta 73 C$ & $+{ }^{2}[53]$ & $+[53]$ & $+[53]$ & $+[53]$ \\
UvrD $\Delta 102 C$ & $-{ }^{1}[54]$ & $-[54]$ & N.D. & $-[54]$ \\
UvrD $\Delta 107 \mathrm{C}$ & $-{ }^{1}[54]$ & N.D. & N.D. \\
\hline
\end{tabular}

\footnotetext{
${ }^{1}$ Experiments were performed in vivo. ${ }^{2}$ Experiments were performed in vitro.+: activity was detected. -: activity was not detected. N.D.:
} not determined.

\section{Single-Molecule Direct Visualization of UvrD $\Delta 40 C$}

In comparison with conventional biochemical and genetic studies that provide data on ensemble averages of multi-molecules, single-molecule fluorescence imaging can assess the real-time behavior of non-averaged individual biomolecules, allowing us to elucidate their detailed dynamical features. [55].

Therefore, single-molecule direct visualization of UvrD $\triangle 40 \mathrm{C}$ was performed to address how the C-terminal amino acids affect the number of helicases bound to DNA, oligomerization, and DNA-unwinding activity.

\subsection{Observation of Multiple UvrD $40 C$ Molecules that Bound to DNA in the Absence of ATP}

To investigate whether or not UvrD $\triangle 40 \mathrm{C}$ binds to DNA in only a monomeric form, single-molecule quantification of $\mathrm{UvrD} \triangle 40 \mathrm{C}$ molecules that bind to DNA was performed under the condition of UvrD $\triangle 40 \mathrm{C}$ molecules alone or in the presence of both $\mathrm{UvrD} \Delta 40 \mathrm{C}$ molecules and adenosine $5^{\prime}$-( $\gamma$-thio)triphosphate (ATP $\left.\gamma S\right)$, a non-hydrolyzable ATP analog. The assay utilized an 18-bp dsDNA with a 20-nucleotide (nt) $3^{\prime}$ ssDNA tail [16,41,56-58]. The DNA was immobilized on the glass surface through streptavidin-biotin interactions and visualized by the fluorescence of $\mathrm{Cy} 3$ attached to one of the oligonucleotides of the DNA [18] (Figure 3A). Then, a Cy5-labeled Cys-Ala mutant (Cy5-UvrD $\Delta 40 \mathrm{C})$ was infused, and the number of $\mathrm{Cy} 5$ photobleaching steps at each Cy3-DNA site was counted using a dual-view apparatus that enabled simultaneous two-color single-molecule imaging. The UvrD $\triangle 40 \mathrm{C}$ mutant only contained single inherent $\mathrm{Cys}\left(\mathrm{Cys}^{52}\right)$ and thus was labeled with a single $\mathrm{Cy} 5$ molecule, with high specificity and a high labeling ratio of $79 \%$. Buffer $\mathrm{U}$ $(6 \mathrm{mM} \mathrm{NaCl}, 2.5 \mathrm{mM} \mathrm{MgCl} 2,10 \%(v / v)$ glycerol, and $25 \mathrm{mM}$ Tris- $\mathrm{HCl}(\mathrm{pH} 7.5)$ ) was used 
in all of the experiments in this section $[18,58]$ unless otherwise mentioned. Figure 3B,C shows a two-step photobleaching event observed in the presence of Cy5-UvrD $\triangle 40 \mathrm{C}$ alone in solution and a three-step photobleaching event observed in the presence of both Cy5UvrD $\triangle 40 \mathrm{C}$ and $1 \mathrm{mM}$ ATP $\gamma \mathrm{S}$ in solution, respectively. The experimentally obtained distributions of the number of photobleaching steps are shown in Figure 3D,E. The fraction of the two photobleaching steps in Figure 3D and the fraction of the three photobleaching steps in Figure 3E demonstrate that at least two or three UvrD $\triangle 40 \mathrm{C}$ molecules can bind DNA under the corresponding solution conditions. Moreover, these results suggest that the presence of ATP $\gamma \mathrm{S}$ made more UvrD $\Delta 40 \mathrm{C}$ molecules bind to DNA, which was observed for wild-type UvrD [18].
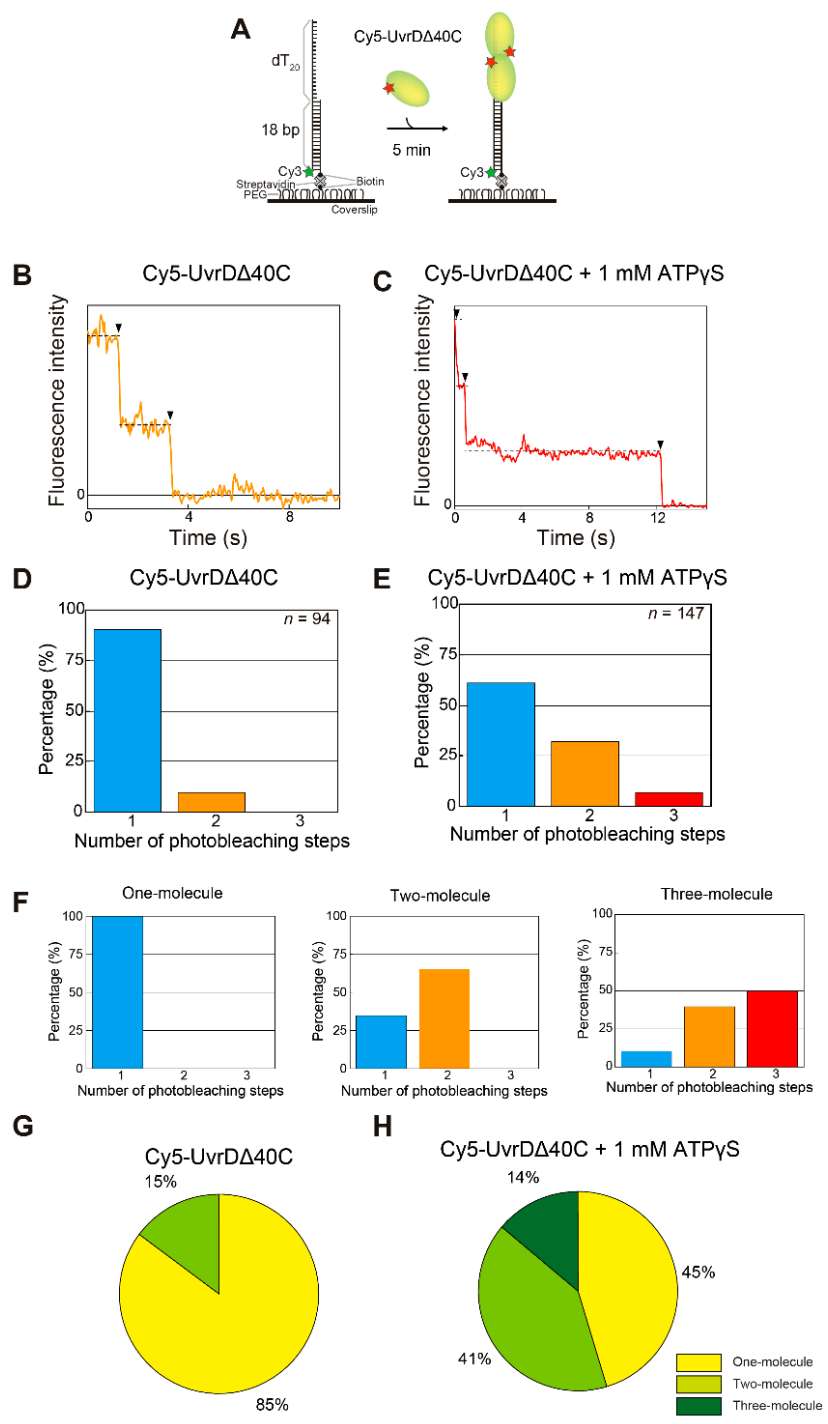

Figure 3. Single-molecule visualization of $\mathrm{Cy} 5-\mathrm{UvrD} \Delta 40 \mathrm{C}$ bound to a DNA substrate in the absence of adenosine triphosphate (ATP): (A) schematic drawing of the assay; $(\mathbf{B}, \mathbf{C})$ the photobleaching processes (indicated by arrowheads) of the fluorescent Cy5-UvrD $\Delta 40 \mathrm{C}$ spots for two steps for UvrD $\Delta 40 \mathrm{C}$ alone (B) and three steps for UvrD $\Delta 40 \mathrm{C}$ and $1 \mathrm{mM}$ adenosine $5^{\prime}-(\gamma$-thio)triphosphate (ATP $\gamma \mathrm{S})$, respectively $(\mathbf{C}) ;(\mathbf{D}, \mathrm{E})$ experimentally obtained distributions of the number of photobleaching steps. The total number of analyzed fluorescent spots is indicated for each condition; (F) theoretical distributions of the number of photobleaching steps for the one-molecule, two-molecule, and three-molecule models; $(\mathbf{G}, \mathbf{H})$ pie charts showing the percentages of each theoretical model, as predicted by the linear combination for $(\mathrm{G}) \mathrm{Cy5}-\mathrm{UvrD} \Delta 40 \mathrm{C}$ alone and for $(\mathbf{H}) \mathrm{Cy5}-\mathrm{UvrD} \Delta 40 \mathrm{C}$ and $1 \mathrm{mM}$ ATP $\gamma \mathrm{S}$. Reproduced with permission from [10]. Copyright 2020, Biophysical Society. 
The predicted distributions of the number of photobleaching steps are shown in Figure 3F. The distributions were calculated based on the labeling ratio of Cy5-UvrD $\triangle 40 \mathrm{C}$ (79\%) for the one-molecule, two-molecule, or three-molecule models of UvrD $\triangle 40 \mathrm{C}$ binding to DNA. Note that non-labeled UvrD $\triangle 40 \mathrm{C}(21 \%)$ was invisible by single-molecule fluorescence imaging. Thus, the percentages of the models contained in the experimentally obtained distributions were obtained by fitting with a linear combination of the theoretical models. Figure 3G,H shows the percentages of the models, indicating that multiple UvrD $\triangle 40 \mathrm{C}$ molecules could bind to DNA.

5.2. Observation of Multiple UvrD $\triangle 40 C$ Molecules' Association to DNA, which Synchronized with the Unwinding Activity in the Presence of ATP

Next, the number of UvrD $\triangle 40 C$ molecules bound to the DNA and DNA unwinding by the molecules in the presence of ATP was simultaneously monitored by single-molecule visualization (Figure 4A). Completion of DNA unwinding was detectable through the disappearance of $\mathrm{Cy} 3$ fluorescence.

A

A

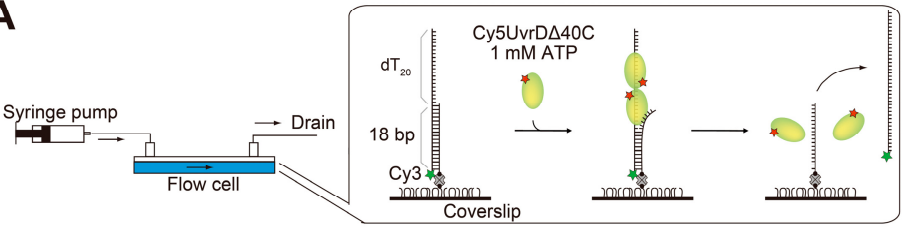

B

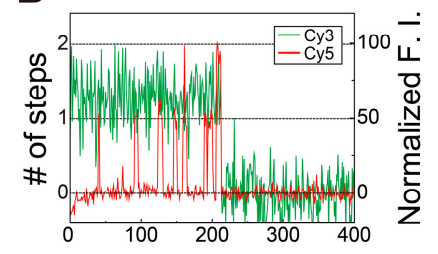

C

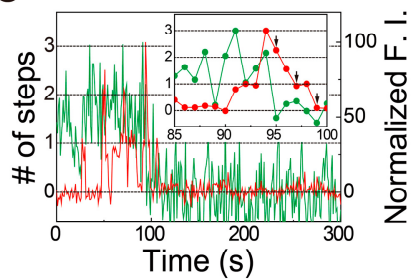

E

E Predicted step distributions

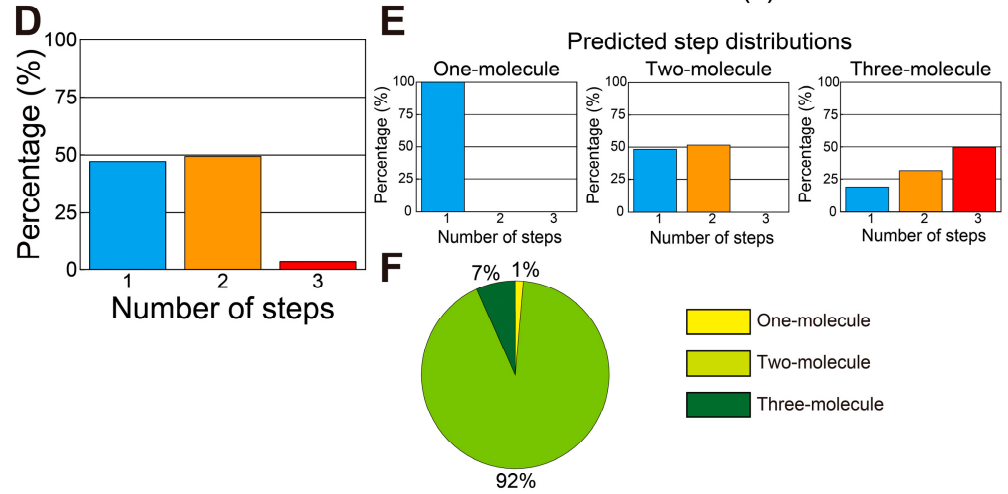

Figure 4. Simultaneous single-molecule visualization of the association/dissociation of Cy5UvrD $\triangle 40 C$ with/from a double-stranded DNA (dsDNA) substrate and unwinding of DNA in the presence of ATP: (A) Schematic drawing of the assay; $(\mathbf{B}, \mathbf{C})$ typical time traces of the Cy3- and Cy5-fluorescence intensities (F.I.), where the Cy5-fluorescence intensity increased in a two-step manner (B) and a three-step manner (indicated with arrows) (C) just before DNA unwinding, resulting in the $\mathrm{Cy} 3$ fluorescence disappearance (D), respectively; (D) experimentally obtained distribution of the number of step changes in the $\mathrm{Cy} 5$ fluorescence; (E) theoretical distributions of the number of $\mathrm{Cy} 5$ fluorescence steps relevant to the completion of DNA unwinding processes; (F) pie chart showing the percentages of each theoretical model, as predicted by linear combination for (E). Reproduced with permission from [10]. Copyright 2020, Biophysical Society.

As observed for wild-type UvrD [18], two- or three-step Cy5 fluorescence changes were observed immediately before finishing unwinding DNA (Figure 4B,C). These observations provide insights into the DNA-unwinding mechanism of UvrD $\triangle 40 \mathrm{C}$. UvrD $\Delta 40 \mathrm{C}$ 
unwinds DNA in the same fashion as wild-type UvrD [18]: DNA unwinding is completed by multiple UvrD $\Delta 40 \mathrm{C}$ molecules. In fact, the ratios of the step numbers for the Cy5 fluorescence changes (Figure 4D) are very similar to the two-molecule model (Figure 4E). The dwell time for the second UvrD $\triangle 40 \mathrm{C}$ association, as well as the estimated number of Cy5 molecules bound per UvrD $\Delta 40 \mathrm{C}$ molecule, were used to work out the ratios of the models. Moreover, the distribution (Figure 4D) was fitted by a linear combination of the theoretical models. The fitting shows that the percentage of the one-molecule model is only $1 \%$ (Figure $4 \mathrm{~F}$ ), demonstrating that two UvrD $\triangle 40 \mathrm{C}$ molecules were engaged in complete DNA unwinding in most cases and that three UvrD $\triangle 40 \mathrm{C}$ molecules also took part in the process in some cases.

Cy5 fluorescence increases corresponding to two or more Cy5-UvrD $\triangle 40 \mathrm{C}$ molecules were also observed under physiologically relevant, high-salt buffer conditions $(200 \mathrm{mM} \mathrm{NaCl})$ (Figure 5), suggesting that multiple UvrD $\triangle 40 \mathrm{C}$ molecules were actually involved in DNA unwinding in vivo, though dimer formation is difficult under these high-salt conditions.

A
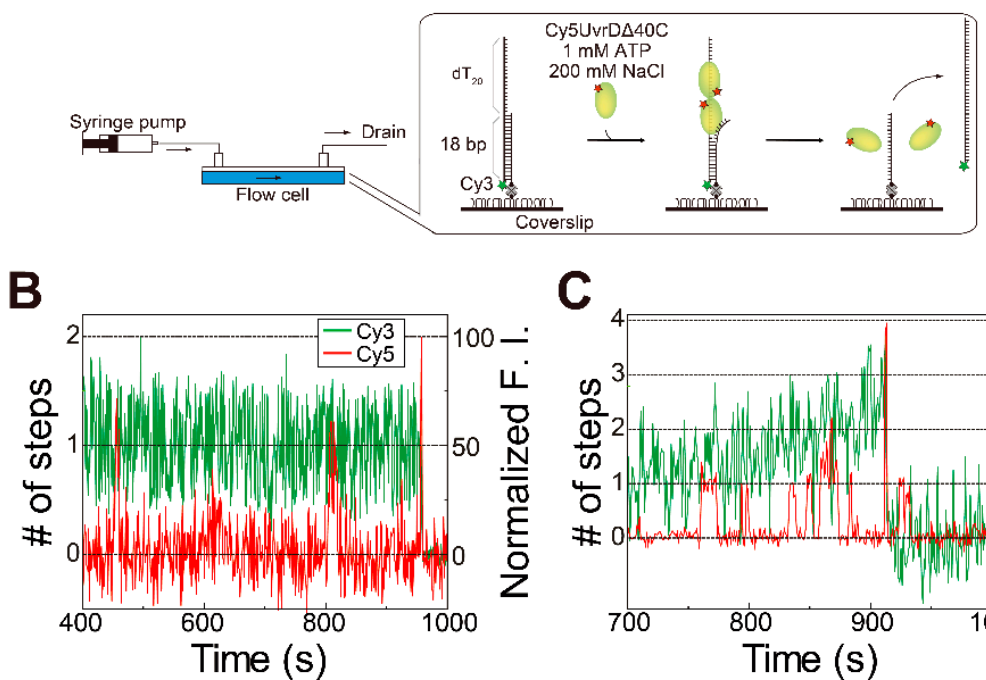

C

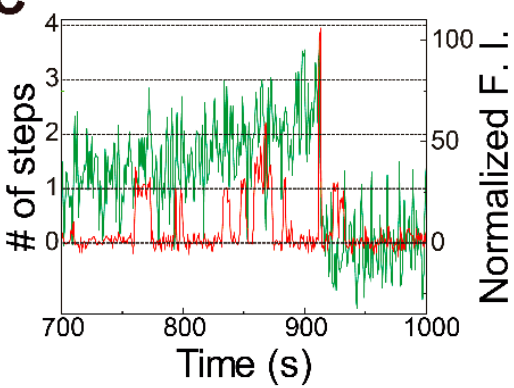

Figure 5. Simultaneous single-molecule visualization of the association/dissociation of Cy5UvrD $\triangle 40 \mathrm{C}$ with/from a dsDNA substrate and unwinding of the DNA in the presence of ATP and $200 \mathrm{mM} \mathrm{NaCl}$ in solution: (A) schematic drawing of the assay; $(\mathbf{B}, \mathbf{C})$ time traces of the Cy3and Cy5-fluorescence intensities (F.I.), where a Cy5-fluorescence intensity increase corresponding to two Cy5-UvrD $\triangle 40 \mathrm{C}$ molecules was observed just before DNA-unwinding completion (Cy5UvrD $\Delta 40 \mathrm{C}$ concentration $=2 \mathrm{nM})(B)$ and where a Cy5-fluorescence intensity increase corresponding to more than two Cy5-UvrD $\triangle 40 \mathrm{C}$ molecules was observed just before DNA-unwinding completion $($ Cy5-UvrD $\Delta 40 \mathrm{C}$ concentration $=10 \mathrm{nM})(\mathrm{C})$, respectively. Reproduced with permission from [10]. Copyright 2020, Biophysical Society.

\subsection{Multiple UvrD $\triangle 40 C$ Molecules that Bound to the DNA Are Likely to Form an Oligomer}

Multiple UvrD $\triangle 40 C$ molecules that unwound DNA were likely to directly self-interact on ssDNA and oligomerize, which was initially proposed from a non-linear sigmoidal dependence of DNA unwinding efficiency on the ratio of wild-type UvrD concentration to DNA concentration [16].

To test this self-interaction hypothesis, single-molecule photobleaching step analysis (Figure 3) was performed using a dsDNA substrate with a shorter $3^{\prime}$ ssDNA tail (18-bp DNA with a 12-nt $3^{\prime}$ ssDNA tail) in the absence of ATP (Figure 6A). The number of UvrD $\triangle 40 C$ molecules that bound to this DNA substrate was supposed to decrease $[18,56]$ since a lower limit of the estimated wild-type UvrD site size on poly $(\mathrm{dT})$ was reported to be $10 \pm 2$ nt [59] and wild-type UvrD molecules were reportedly hard to bind to blunt dsDNA [18]. However, the analysis revealed that two UvrD $\Delta 40 \mathrm{C}$ molecules were bound even 
to the DNA (Figure 6B,C). Moreover, the single-molecule DNA-unwinding assay (Figure 4) using the DNA substrate in the presence of ATP demonstrated (Figure 6D) that multiple UvrD $\triangle 40 \mathrm{C}$ molecules still participate in the DNA-unwinding process (Figure $6 \mathrm{E}, \mathrm{F}$ ). These results strongly support the self-interaction or oligomerization of $\mathrm{UvrD} \triangle 40 \mathrm{C}$ molecules on DNA.

A
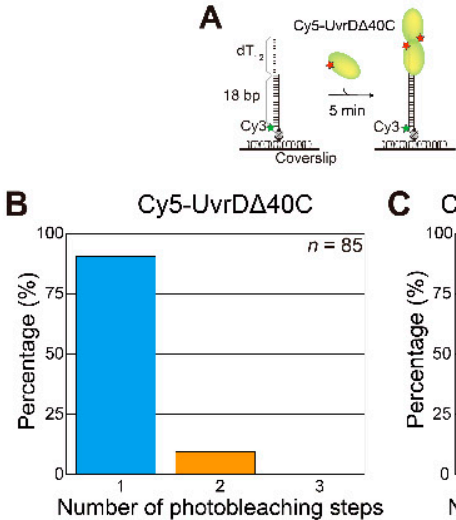

C Cy5-UvrD $\triangle 40 \mathrm{C}+1 \mathrm{mM}$ ATPYS

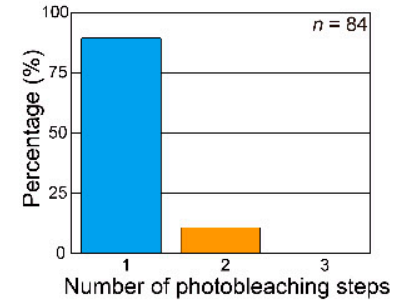

D

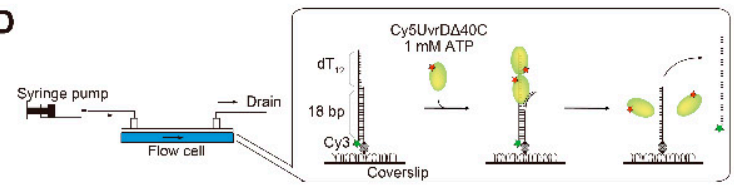

E

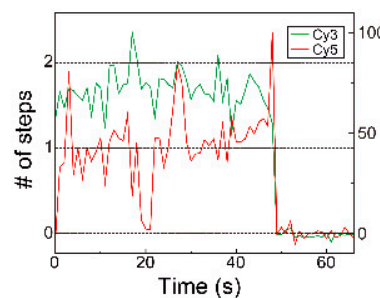

$\mathbf{F}$

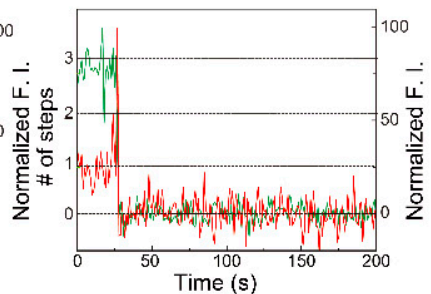

Figure 6. Single-molecule visualization of Cy5-UvrD $\triangle 40 \mathrm{C}$ bound to a 18-base pair (bp) dsDNA substrate with a 12-nt $3^{\prime}$ single-stranded DNA (ssDNA) tail in the absence or the presence of ATP: (A) schematic drawing of the assay for the absence of nucleotides or the presence of $1 \mathrm{mM} \mathrm{ATP} \gamma \mathrm{S} ;(\mathbf{B}, \mathbf{C})$ experimentally obtained distributions of the number of photobleaching steps for the Cy5-UvrD $\triangle 40 \mathrm{C}$ that bound to an 18-bp DNA with a 12-nt 3' ssDNA tail in solutions containing $2 \mathrm{nM}$ Cy5-UvrD $\Delta 40 \mathrm{C}$ alone (B) and $2 \mathrm{nM}$ Cy5-UvrD $\Delta 40 \mathrm{C}$ and $1 \mathrm{mM}$ ATP $\gamma \mathrm{S}(\mathrm{C})$, respectively. The total number of analyzed fluorescent spots is indicated for each condition; (D) schematic drawing of the assay for the presence of $1 \mathrm{mM}$ ATP; (E,F) simultaneous single-molecule visualization of the association/dissociation of Cy5-UvrD $\Delta 40 \mathrm{C}$ with/from the dsDNA substrate and unwinding of the DNA in a solution containing $10 \mathrm{nM} \mathrm{Cy5-UvrD} \triangle 40 \mathrm{C}$ and $1 \mathrm{mM}$ ATP; (E) time traces of the Cy3- and Cy5-fluorescence intensities (F.I.), where the Cy5-fluorescence intensity increased in a two-step manner just before DNA unwinding resulting in the Cy3 fluorescence disappearance; $(\mathbf{F})$ time traces of the Cy3- and Cy5-fluorescence intensities, where the maximum Cy5-fluorescence intensity was supposed to come from three Cy5-UvrD $\Delta 40 \mathrm{C}$ molecules just before the DNA unwinding process. Reproduced with permission from [10]. Copyright 2020, Biophysical Society.

The $3^{\prime}$ ssDNA length (12 nt) was reported to be the minimum length to complete unwinding dsDNA as long as $18 \mathrm{bp}$ [16], which implies that oligomerization of the multiple UvrD $\triangle 40 C$ molecules along ssDNA is crucial to unwinding DNA. Nguyen et al. showed that the $2 \mathrm{~B}$ domain of the UvrD that first bound to DNA was altered to a more closed conformation by the binding of a second UvrD to the first bound UvrD (dimerization), activating DNA-unwinding activity [21]. These findings also support that multiple $\mathrm{UvrD} \triangle 40 \mathrm{C}$ molecules that were involved in DNA unwinding made some physical contact.

The opposing "independent monomer" model has been proposed for some nonhexameric helicases such as RecQ [26] and Dda [36]. This model was built based on the notion that multiple helicases participate in DNA unwinding, but they unwind DNA without self-interaction or oligomerization. Note that this model does not exclude some interaction between helicases. Although UvrD might unwind DNA in this manner, this model was not applicable to UvrD [16].

\subsection{Transient Two UvrD Bound State Just before Completion of the DNA-Unwinding Process}

The dwell time between the appearance of the second step of the Cy5 fluorescence increase and the completion of the DNA-unwinding process, which is defined as $\tau_{2}$, is indicated in Figure 7A,B for Cy5- labeled wild-type UvrD and Cy5-UvrD $\Delta 40 \mathrm{C}$ (as same as Figure $4 B$ ), respectively. Figure 7 C,D shows their $\tau_{2}$ distributions. 

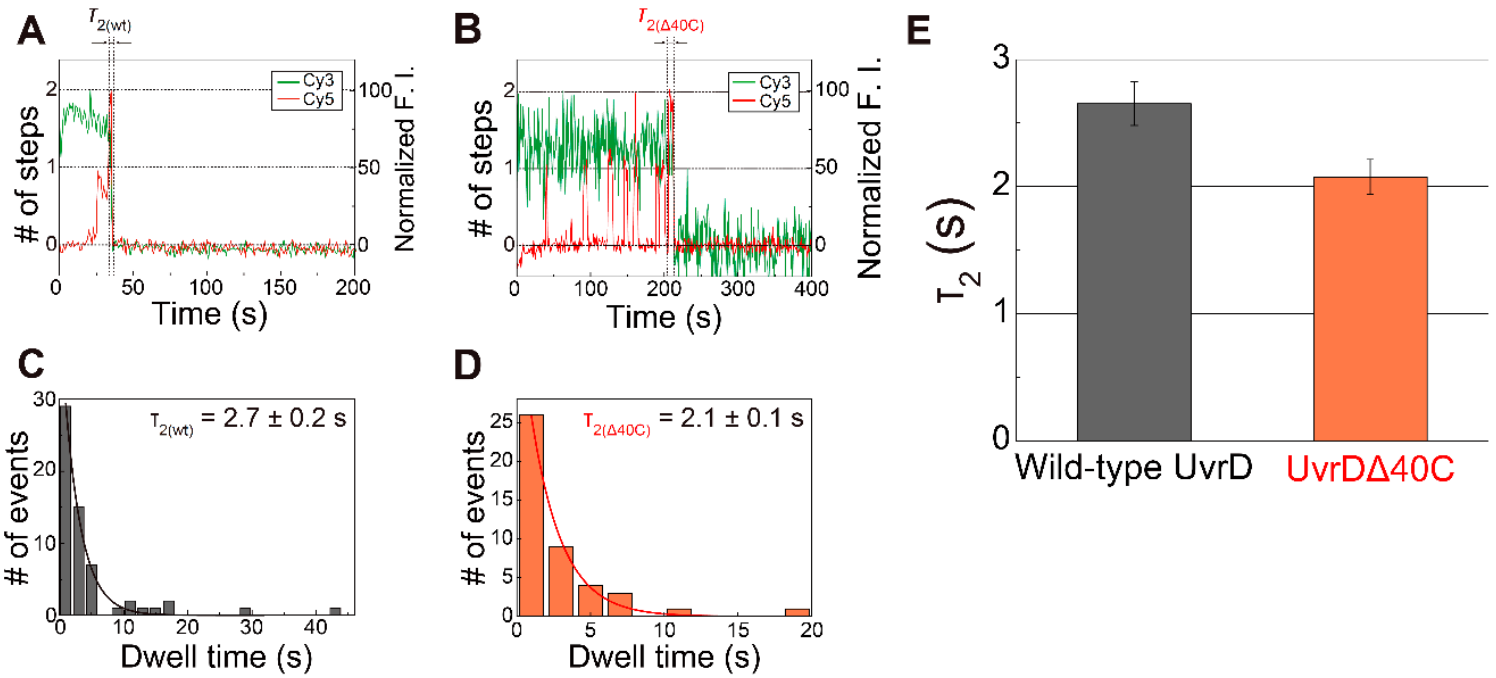

Figure 7. The dwell time $\left(\tau_{2}\right)$ between the appearance of the second step and completion of the DNA-unwinding process: $(\mathbf{A}, \mathbf{B})$ typical time traces of the Cy3- and Cy5-fluorescence intensities (F.I.) for Cy5- labeled wild-type UvrD (A) and Cy5- labeled UvrD $\Delta 40 \mathrm{C}(\mathbf{B})$ (Figure $4 \mathrm{~B})$, respectively, where each dwell time $\left(\tau_{2(\mathrm{wt})}\right.$ and $\left.\tau_{2(\Delta 40 \mathrm{C})}\right)$ is indicated; (C,D) $\tau_{2}$ distributions for Cy5- labeled wild-type $\operatorname{UvrD}(\mathbf{C})$ and Cy5- UvrD $\triangle 40 C$ (D), respectively, the mean dwell time, which was obtained by single exponential fittings were $2.7 \pm 0.2 \mathrm{~s}$ for Cy5- labeled wild-type UvrD and $2.1 \pm 0.1 \mathrm{~s}$ for Cy5-UvrD $\Delta 40 \mathrm{C}$; (E) comparison of the obtained $\tau_{2}$. The error bars represent the standard errors. Reproduced with permission from [10,18]. Copyright 2013, 2020, Biophysical Society.

The two UvrD $\triangle 40 \mathrm{C}$ molecules that bound to the DNA are likely to form an oligomer. Then, three kinetic steps are supposed to take place during the mean dwell time of two UvrD $\triangle 40 \mathrm{C}$-bound states $\left(\tau_{2(\Delta 40 \mathrm{C})}=2.1 \pm 0.1 \mathrm{~s}\right)$. These are: (i) late-coming $\mathrm{UvrD} \Delta 40 \mathrm{C}$ molecule(s) translocated along ssDNA and forming an oligomer with earlier bound UvrD $\triangle 40 \mathrm{C}$ molecule(s); (ii) the oligomer isomerized to become a productive oligomer that was prepared for unwinding DNA; and (iii) the isomerized oligomer unwinding DNA. Since UvrD $\Delta 40 \mathrm{C}$ has similar helicase activity to wild-type $\operatorname{UvrD}[32,54]$, UvrD $\Delta 40 \mathrm{C}$ might translocate along ssDNA at the same speed as wild-type UvrD (translocation rate along $\mathrm{dT}$ of $\sim 190 \mathrm{nt} \mathrm{s}^{-1}$ [60] and a processivity of $769 \pm 1 \mathrm{nt}$ [61]) and can encounter pre-bound UvrD $\triangle 40 \mathrm{C}$ monomer(s) in less than $0.1 \mathrm{~s}$. Then, since the unwinding rate and the processivity of wild-type UvrD are reported to be $68 \pm 9 \mathrm{bp} / \mathrm{s}$ [16] and $40-50 \mathrm{bp}$ [62], respectively, the productive UvrD $\triangle 40 \mathrm{C}$ oligomer must complete unwinding the 18-bp dsDNA substrate in $<0.5 \mathrm{~s}$ without dissociating from the DNA. To sum up, unwinding of the 18-bp dsDNA substrate would be completed in less than $0.5 \mathrm{~s}$ after the late-coming UvrD $\triangle 40 \mathrm{C}$ monomer bound to the DNA.

Interestingly, UvrD $\triangle 40 \mathrm{C}$ has a mean $\tau_{2}$ shorter than wild-type UvrD [18] (Figure 7E). This result suggests that $\mathrm{UvrD} \triangle 40 \mathrm{C}$ molecules isomerize faster than wild-type UvrD molecules, which is consistent with the result by Mechanic et al., in which UvrD $\triangle 40 C$ molecules had a slightly higher DNA unwinding rate than wild-type UvrD molecules [32]. Therefore, the C-terminal 40-amino acid deletion should alter the isomerization process in some way.

\subsection{Association/Dissociation Rates for the UvrD $440 C-D N A$ Interaction}

The observed single-molecule UvrD $\triangle 40 \mathrm{C}$ association/dissociation events (Figure 4B,C) enabled the determination of the kinetic features of the UvrD $\triangle 40 \mathrm{C}-\mathrm{DNA}$ interaction. The traces with stepwise Cy5 fluorescence increases or decreases were considered to be UvrD $\triangle 40 \mathrm{C}$ associations or dissociations. The kinetic scheme of UvrD-DNA interactions is shown in Figure 8A, which was proposed in the author's past single-molecule direct visualization for wild-type UvrD [18]. 
A
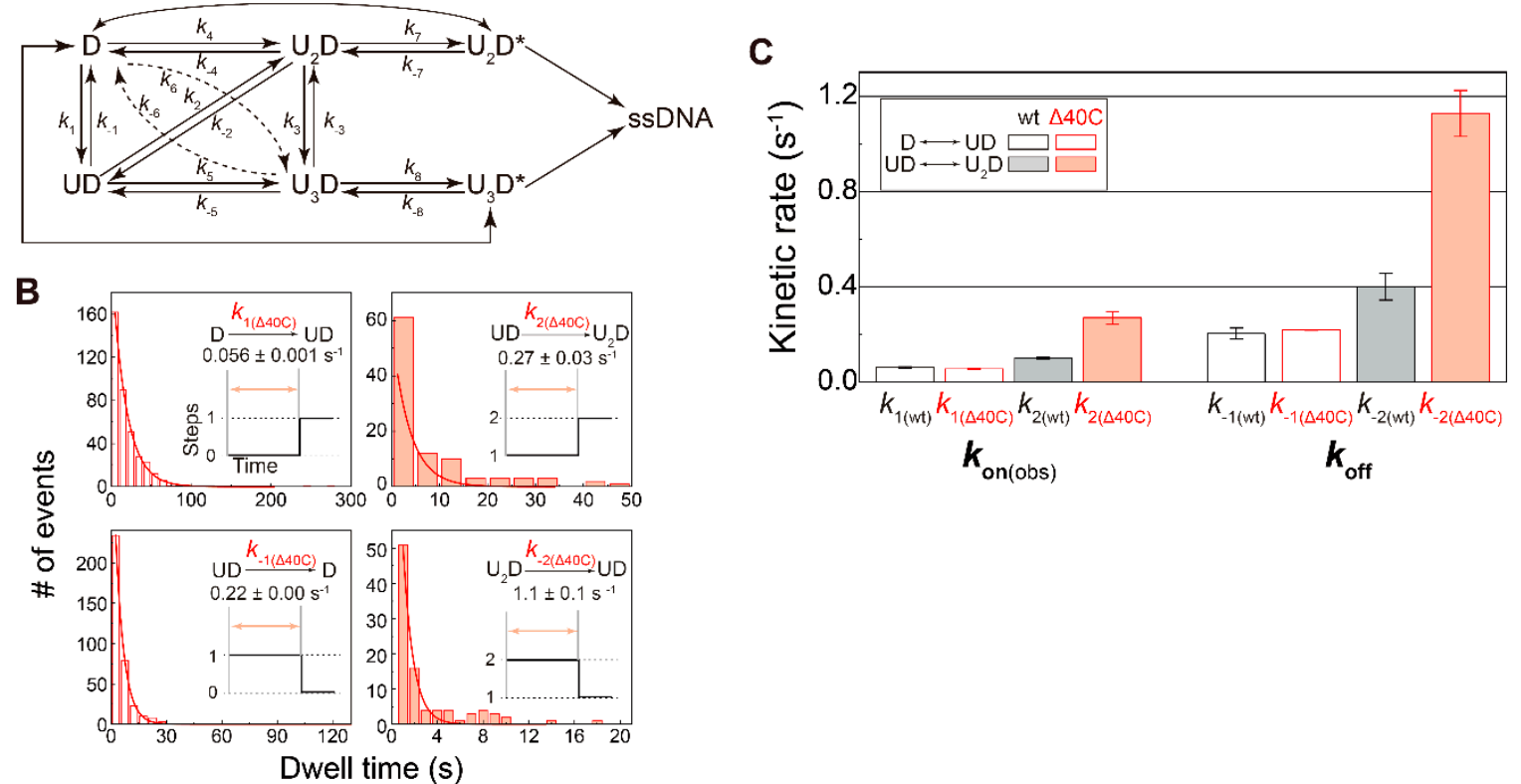

Figure 8. Association- and dissociation-rate constants: (A) kinetic scheme of the UvrD-DNA interaction. U and D represent UvrD and DNA, respectively; (B) dwell-time distributions of the indicated states. Association- and dissociation-rate constants were obtained by single exponential fit of each distribution. $k_{1}$ and $k_{2}$ are association rate constants under $2 \mathrm{nM}$ UvrD $\Delta 40 C$ concentration; (C) comparison of the obtained rate constants between UvrD $\Delta 40 C$ and wild-type UvrD. $K_{\text {on(obs) }}$ are the observed association rate constants under $2 \mathrm{nM} \mathrm{UvrD} \Delta 40 \mathrm{C}$ concentration. The error bars represent standard errors. Reproduced with permission from [10]. Copyright 2020, Biophysical Society.

The dwell-time distributions for some kinetic steps are shown in Figure 8B. Dwell time for the dissociation events immediately before completion of the DNA-unwinding process was excluded from the distributions. Each single exponential fitting provided the corresponding rate constants. Note that the more UvrD $\Delta 40 \mathrm{C}$ molecules were involved in the association/dissociation processes, the higher rate constants were estimated, which was already observed for wild-type UvrD (Figure 8C).

For the first bound UvrD, UvrD $\triangle 40 \mathrm{C}$ exhibited association and dissociation rates comparable to wild-type UvrD. In contrast, for the second bound UvrD, UvrD $\Delta 40 \mathrm{C}$ had higher rates (approximately 2.5-fold higher than wild-type UvrD). These results represented that the lifetime of a UvrD $\triangle 40 \mathrm{C}$ oligomer was shorter than that of wild-type UvrD.

\section{Summary}

This paper has given an overview of past and recent studies that proposed helicase mechanisms and investigated the effect of $\mathrm{C}$-terminal amino acid truncation on helicase and dimerization activities, primarily on the non-hexameric E. coli SF1 UvrD helicase. Among non-hexameric SF1 and SF2 helicases, the roles of the C-terminus were well studied for SF2 DEAD-box helicases. These studies showed that the $\mathrm{C}$-terminus is a key region of nucleic acid binding and dimerization activities that are directly linked to the DNA unwinding function. To illustrate how the C-terminus affects the functions of SF1 helicases, I have introduced my latest single-molecule direct visualization study on UvrD $\Delta 40 \mathrm{C}$, which was used for studies proposing the monomer helicase model, and shown how the truncation of C-terminal amino acids outside the conserved helicase domains affects the helicase-DNA interaction and dimerization activities. Contrary to the proposed model, it has been shown that multiple UvrD $\Delta 40 \mathrm{C}$ molecules jointly participated in DNA unwinding, presumably by forming an oligomer. Thus, single-molecule observations can help us increase our understanding of protein-nucleic acid interactions. It can also identify transient and 
minor populations that are usually overlooked by conventional ensemble averaging-based measurements and can determine kinetic rate constants.

Other single-molecule observations by single-molecule DNA-manipulation [17] and by direct visualization of single UvrD molecules [19] from other groups support the oligomer model. The possible self-interaction or oligomer formation of UvrD discussed in this review was also indicated by these single-molecule studies. In addition, data from a recent single-molecule fluorescence resonance energy transfer (FRET) study showed that the $2 \mathrm{~B}$ domain of the UvrD that first bound to DNA was altered to a more closed conformation by the binding of a second UvrD to the first bound UvrD (dimerization), activating DNAunwinding activity [21]. The conformational change in the 2B domain, another significant feature of SF1 helicases, was visualized by single-molecule force-fluorescence microscopy, in which single-molecule visualization of wild-type UvrD molecules and DNA-unwinding activity monitoring with optical tweezers were simultaneously feasible [20].

The single-molecule UvrD $\triangle 40 \mathrm{C}$ visualization study introduced in this review, which can be applied to other helicases, addressed how C-terminal amino acids affect the number of helicases bound to DNA, oligomerization, and unwinding activity. Single-molecule microscopy such as single-molecule visualization and single-molecule DNA manipulation will serve as a means to explore how the DNA-binding and DNA-unwinding activities of helicases are affected by their C-terminus and partner proteins.

Funding: This work was supported by Japan Society for the Promotion of Science (JSPS) Grantsin-Aid for Scientific Research (KAKENHI), under grant numbers JP15H01648, JP17H05892, and JP18K06169.

Institutional Review Board Statement: Not applicable.

Informed Consent Statement: Not applicable.

Data Availability Statement: The data that support the findings of this study are available from the corresponding author upon reasonable request.

Conflicts of Interest: The author declares that there are no conflicts of interest.

\section{Abbreviations}

\begin{tabular}{|c|c|}
\hline ATP & adenosine triphosphate \\
\hline $\mathrm{ATP} \gamma \mathrm{S}$ & adenosine $5^{\prime}-(\gamma$-thio)triphosphate \\
\hline B. stearothermophilus & Bacillus stearothermophilus \\
\hline bp & base pair \\
\hline dsDNA & double-stranded DNA \\
\hline E. coli & Escherichia coli \\
\hline F.I. & fluorescence intensities \\
\hline FCCS & fluorescence cross-correlation spectroscopy \\
\hline FRET & fluorescence resonance energy transfer \\
\hline G. stearothermophilus & Geobacillus stearothermophilus \\
\hline N.D. & not determined \\
\hline nt & nucleotide \\
\hline SF & superfamily \\
\hline ssDNA & single-stranded DNA \\
\hline T. thermophilus & Thermus thermophilus \\
\hline UvrD $\Delta 102 C$ & UvrD mutant lacking the C-terminal 102 amino acids \\
\hline UvrD $\triangle 107 \mathrm{C}$ & UvrD mutant lacking the C-terminal 107 amino acids \\
\hline UvrD $\triangle 40 \mathrm{C}$ & UvrD mutant lacking the C-terminal 40 amino acids \\
\hline UvrD $\Delta 73 C$ & UvrD mutant lacking the $\mathrm{C}$-terminal 73 amino acids \\
\hline
\end{tabular}




\section{References}

1. Singleton, M.R.; Dillingham, M.S.; Wigley, D.B. Structure and Mechanism of Helicases and Nucleic Acid Translocases. Annu. Rev. Biochem. 2007, 76, 23-50. [CrossRef] [PubMed]

2. Fairman-Williams, M.E.; Guenther, U.-P.; Jankowsky, E. SF1 and SF2 helicases: Family matters. Curr. Opin. Struct. Biol. 2010, 20, 313-324. [CrossRef] [PubMed]

3. Raney, K.D.; Byrd, A.K.; Aarattuthodiyil, S. Structure and Mechanisms of SF1 DNA Helicases. Neurotransm. Interact. Cogn. Funct. 2012, 767, 17-46. [CrossRef]

4. Singleton, M.R.; Sawaya, M.R.; Ellenberger, T.; Wigley, D.B. Crystal Structure of T7 Gene 4 Ring Helicase Indicates a Mechanism for Sequential Hydrolysis of Nucleotides. Cell 2000, 101, 589-600. [CrossRef]

5. Enemark, E.J.; Joshua-Tor, L. On helicases and other motor proteins. Curr. Opin. Struct. Biol. 2008, 18, 243-257. [CrossRef]

6. Lee, J.Y.; Yang, W. UvrD Helicase Unwinds DNA One Base Pair at a Time by a Two-Part Power Stroke. Cell 2006, 127, 1349-1360. [CrossRef] [PubMed]

7. Jia, H.; Korolev, S.; Niedziela-Majka, A.; Maluf, N.K.; Gauss, G.H.; Myong, S.; Ha, T.; Waksman, G.; Lohman, T.M. Rotations of the 2B Sub-domain of E. coli UvrD Helicase/Translocase Coupled to Nucleotide and DNA Binding. J. Mol. Biol. 2011, 411, 633-648. [CrossRef]

8. Korolev, S.; Hsieh, J.; Gauss, G.H.; Lohman, T.M.; Waksman, G. Major Domain Swiveling Revealed by the Crystal Structures of Complexes of E. coli Rep Helicase Bound to Single-Stranded DNA and ADP. Cell 1997, 90, 635-647. [CrossRef]

9. Velankar, S.S.; Soultanas, P.; Dillingham, M.S.; Subramanya, H.S.; Wigley, D.B. Crystal Structures of Complexes of PcrA DNA Helicase with a DNA Substrate Indicate an Inchworm Mechanism. Cell 1999, 97, 75-84. [CrossRef]

10. Yokota, H. DNA-Unwinding Dynamics of Escherichia coli UvrD Lacking the C-Terminal 40 Amino Acids. Biophys. J. 2020, 118, 1634-1648. [CrossRef]

11. Gorbalenya, A.E.; Koonin, E.V. Helicases: Amino acid sequence comparisons and structure-function relationships. Curr. Opin. Struct. Biol. 1993, 3, 419-429. [CrossRef]

12. Gilhooly, N.S.; Gwynn, E.J.; Dillingham, M.S. Superfamily 1 helicases. Front. Biosci. 2013, 5, 206-216. [CrossRef] [PubMed]

13. Pettersen, E.F.; Goddard, T.D.; Huang, C.C.; Couch, G.S.; Greenblatt, D.M.; Meng, E.C.; Ferrin, T.E. UCSF Chimera-A visualization system for exploratory research and analysis. J. Comput. Chem. 2004, 25, 1605-1612. [CrossRef] [PubMed]

14. Larkin, M.A.; Blackshields, G.; Brown, N.P.; Chenna, R.; Mcgettigan, P.A.; McWilliam, H.; Valentin, F.; Wallace, I.M.; Wilm, A.; Lopez, R.; et al. Clustal W and Clustal X version 2.0. Bioinformatics 2007, 23, 2947-2948. [CrossRef]

15. Robert, X.; Gouet, P. Deciphering key features in protein structures with the new ENDscript server. Nucleic Acids Res. 2014, 42, W320-W324. [CrossRef]

16. Maluf, N.K.; Fischer, C.J.; Lohman, T.M. A Dimer of Escherichia coli UvrD is the Active Form of the Helicase In Vitro. J. Mol. Biol. 2003, 325, 913-935. [CrossRef]

17. Sun, B.; Wei, K.-J.; Zhang, B.; Zhang, X.-H.; Dou, S.-X.; Ming, L.; Xi, X.G. Impediment of E. coli UvrD by DNA-destabilizing force reveals a strained-inchworm mechanism of DNA unwinding. EMBO J. 2008, 27, 3279-3287. [CrossRef]

18. Yokota, H.; Chujo, Y.A.; Harada, Y. Single-Molecule Imaging of the Oligomer Formation of the Nonhexameric Escherichia coli UvrD Helicase. Biophys. J. 2013, 104, 924-933. [CrossRef]

19. Lee, K.S.; Balci, H.; Jia, H.; Lohman, T.M.; Ha, T. Direct imaging of single UvrD helicase dynamics on long single-stranded DNA. Nat. Commun. 2013, 4, 1878. [CrossRef]

20. Comstock, M.J.; Whitley, K.D.; Jia, H.; Sokoloski, J.; Lohman, T.M.; Ha, T.; Chemla, Y.R. Direct observation of structure-function relationship in a nucleic acid-processing enzyme. Science 2015, 348, 352-354. [CrossRef]

21. Nguyen, B.; Ordabayev, Y.; Sokoloski, J.E.; Weiland, E.; Lohman, T.M. Large domain movements upon UvrD dimerization and helicase activation. Proc. Natl. Acad. Sci. USA 2017, 114, 12178-12183. [CrossRef] [PubMed]

22. Wong, I.; Lohman, T.M. Allosteric Effects of Nucleotide Cofactors on Escherichia coli Rep Helicase \& DNA Binding. Science 1992, 256, 350-355. [CrossRef] [PubMed]

23. Cheng, W.; Hsieh, J.; Brendza, K.M.; Lohman, T.M. E. coli Rep oligomers are required to initiate DNA unwinding in vitro. J. Mol. Biol. 2001, 310, 327-350. [CrossRef] [PubMed]

24. Ilangovan, A.; Kay, C.W.M.; Roier, S.; El Mkami, H.; Salvadori, E.; Zechner, E.L.; Zanetti, G.; Waksman, G. Cryo-EM Structure of a Relaxase Reveals the Molecular Basis of DNA Unwinding during Bacterial Conjugation. Cell 2017, 169, 708-721. [CrossRef] [PubMed]

25. Yang, Y.; Dou, S.-X.; Ren, H.; Wang, P.-Y.; Zhang, X.-D.; Qian, M.; Pan, B.-Y.; Xi, X.G. Evidence for a functional dimeric form of the PcrA helicase in DNA unwinding. Nucleic Acids Res. 2008, 36, 1976-1989. [CrossRef]

26. Rad, B.; Forget, A.L.; Baskin, R.J.; Kowalczykowski, S.C. Single-molecule visualization of RecQ helicase reveals DNA melting, nucleation, and assembly are required for processive DNA unwinding. Proc. Natl. Acad. Sci. USA 2015, 112, E6852-E6861. [CrossRef]

27. Sikora, B.; Chen, Y.; Lichti, C.F.; Harrison, M.K.; Jennings, T.A.; Tang, Y.; Tackett, A.J.; Jordan, J.B.; Sakon, J.; Cameron, C.E.; et al. Hepatitis C virus NS3 helicase forms oligomeric structures that exhibit optimal DNA unwinding activity in vitro. J. Biol. Chem. 2008, 283, 11516-11525. [CrossRef]

28. Xu, L.; Wang, L.; Peng, J.; Li, F.; Wu, L.; Zhang, B.; Lv, M.; Zhang, J.; Gong, Q.; Zhang, R.; et al. Insights into the Structure of Dimeric RNA Helicase CsdA and Indispensable Role of Its C-Terminal Regions. Structure 2017, 25, 1795-1808.e5. [CrossRef] 
29. Liou, G.-G.; Chang, H.-Y.; Lin, C.-S.; Lin-Chao, S. DEAD Box RhlB RNA Helicase Physically Associates with Exoribonuclease PNPase to Degrade Double-stranded RNA Independent of the Degradosome-assembling Region of RNase E. J. Biol. Chem. 2002, 277, 41157-41162. [CrossRef]

30. Huen, J.; Lin, C.-L.; Golzarroshan, B.; Yi, W.-L.; Yang, W.-Z.; Yuan, H.S. Structural Insights into a Unique Dimeric DEAD-Box Helicase CshA that Promotes RNA Decay. Structure 2017, 25, 469-481. [CrossRef]

31. Klostermeier, D.; Rudolph, M.G. A novel dimerization motif in the C-terminal domain of the Thermus thermophilus DEAD box helicase Hera confers substantial flexibility. Nucleic Acids Res. 2008, 37, 421-430. [CrossRef] [PubMed]

32. Mechanic, L.E.; Hall, M.C.; Matson, S.W. Escherichia coli DNA Helicase II Is Active as a Monomer. J. Biol. Chem. 1999, $274,12488-12498$. [CrossRef] [PubMed]

33. Chisty, L.T.; Toseland, C.P.; Fili, N.; Mashanov, G.I.; Dillingham, M.S.; Molloy, J.E.; Webb, M.R. Monomeric PcrA helicase processively unwinds plasmid lengths of DNA in the presence of the initiator protein RepD. Nucleic Acids Res. 2013, 41, 5010-5023. [CrossRef] [PubMed]

34. Sikora, B.; Eoff, R.L.; Matson, S.W.; Raney, K.D. DNA Unwinding by Escherichia coli DNA Helicase I (TraI) Provides Evidence for a Processive Monomeric Molecular Motor. J. Biol. Chem. 2006, 281, 36110-36116. [CrossRef] [PubMed]

35. Nanduri, B.; Byrd, A.K.; Eoff, R.L.; Tackett, A.J.; Raney, K.D. Pre-steady-state DNA unwinding by bacteriophage T4 Dda helicase reveals a monomeric molecular motor. Proc. Natl. Acad. Sci. USA 2002, 99, 14722-14727. [CrossRef]

36. Eoff, R.L.; Raney, K.D. Kinetic Mechanism for DNA Unwinding by Multiple Molecules of Dda Helicase Aligned on DNA. Biochemistry 2010, 49, 4543-4553. [CrossRef]

37. Xu, H.Q.; Deprez, E.; Zhang, A.H.; Tauc, P.; Ladjimi, M.M.; Brochon, J.C.; Auclair, C.; Xi, X.G. The Escherichia coli RecQ helicase functions as a monomer. J. Biol. Chem. 2003, 278, 34925-34933.

38. Zhang, X.D.; Dou, S.X.; Xie, P.; Hu, J.S.; Wang, P.Y.; Xi, X.G. Escherichia coli RecQ is a rapid, efficient, and monomeric helicase J. Biol. Chem. 2006, 281, 12655-12663. [CrossRef]

39. Li, N.; Henry, E.; Guiot, E.; Rigolet, P.; Brochon, J.C.; Xi, X.G.; Deprez, E. Multiple Escherichia coli RecQ helicase monomers cooperate to unwind long DNA substrates: A fluorescence cross-correlation spectroscopy study. J. Biol. Chem. 2010, 285, 6922-6936. [CrossRef]

40. Kim, J.L.; Morgenstern, K.A.; Griffith, J.P.; Dwyer, M.D.; Thomson, J.A.; Murcko, M.A.; Lin, C.; Caron, P.R. Hepatitis C virus NS3 RNA helicase domain with a bound oligonucleotide: The crystal structure provides insights into the mode of unwinding. Structure 1998, 6, 89-100. [CrossRef]

41. Maluf, N.K.; Lohman, T.M. Self-association Equilibria of Escherichia coli UvrD Helicase Studied by Analytical Ultracentrifugation. J. Mol. Biol. 2003, 325, 889-912. [CrossRef]

42. Niedziela-Majka, A.; Chesnik, M.A.; Tomko, E.J.; Lohman, T.M. Bacillus stearothermophilus PcrA Monomer Is a Single-stranded DNA Translocase but Not a Processive Helicase in Vitro. J. Biol. Chem. 2007, 282, 27076-27085. [CrossRef] [PubMed]

43. Park, E.; Guzder, S.N.; Koken, M.H.; Jaspers-Dekker, I.; Weeda, G.; Hoeijmakers, J.H.; Prakash, S. RAD25 (SSL2), the yeast homolog of the human xeroderma pigmentosum group B DNA repair gene, is essential for viability. Proc. Natl. Acad. Sci. USA 1992, 89, 11416-11420. [CrossRef] [PubMed]

44. Ziegelin, G.; Linderoth, N.A.; Calendar, R.; Lanka, E. Domain structure of phage P4 alpha protein deduced by mutational analysis. J. Bacteriol. 1995, 177, 4333-4341. [CrossRef] [PubMed]

45. Yu, C.-E.; Oshima, J.; Fu, Y.-H.; Wijsman, E.M.; Hisama, F.; Alisch, R.; Matthews, S.; Nakura, J.; Miki, T.; Ouais, S.; et al. Positional cloning of the Werner's syndrome gene. Science 1996, 272, 258-262. [CrossRef]

46. Von Kobbe, C.; Thomä, N.H.; Czyzewski, B.K.; Pavletich, N.P.; Bohr, V.A. Werner Syndrome Protein Contains Three Structurespecific DNA Binding Domains. J. Biol. Chem. 2003, 278, 52997-53006. [CrossRef]

47. Rudolph, M.G.; Klostermeier, D. When core competence is not enough: Functional interplay of the DEAD-box helicase core with ancillary domains and auxiliary factors in RNA binding and unwinding. Biol. Chem. 2015, 396, 849-865. [CrossRef]

48. Giraud, C.; Hausmann, S.; Lemeille, S.; Prados, J.; Redder, P.; Linder, P. The C-terminal region of the RNA helicase CshA is required for the interaction with the degradosome and turnover of bulk RNA in the opportunistic pathogen Staphylococcus aureus. RNA Biol. 2015, 12, 658-674. [CrossRef]

49. Mohr, G.; Del Campo, M.; Mohr, S.; Yang, Q.; Jia, H.; Jankowsky, E.; Lambowitz, A.M. Function of the C-terminal Domain of the DEAD-box Protein Mss116p Analyzed in Vivo and in Vitro. J. Mol. Biol. 2008, 375, 1344-1364. [CrossRef]

50. Kossen, K.; Uhlenbeck, O.C. Cloning and biochemical characterization of Bacillus subtilis YxiN, a DEAD protein specifically activated by $23 S$ rRNA: Delineation of a novel sub-family of bacterial DEAD proteins. Nucleic Acids Res. 1999, 27, 3811-3820. [CrossRef]

51. Yang, L.; Yang, J.; Huang, Y.; Liu, Z.-R. Phosphorylation of p68 RNA helicase regulates RNA binding by the C-terminal domain of the protein. Biochem. Biophys. Res. Commun. 2004, 314, 622-630. [CrossRef] [PubMed]

52. Lohman, T.M.; Bjornson, K.P. Mechanisms of helicase-catalyzed DNA unwinding. Annu. Rev. Biochem. 1996, 65, 169-214. [CrossRef] [PubMed]

53. Manelyte, L.; Guy, C.P.; Smith, R.M.; Dillingham, M.S.; McGlynn, P.; Savery, N. The unstructured C-terminal extension of UvrD interacts with UvrB, but is dispensable for nucleotide excision repair. DNA Repair 2009, 8, 1300-1310. [CrossRef] [PubMed]

54. Mechanic, L.E.; Latta, M.E.; Matson, S.W. A region near the C-terminal end of Escherichia coli DNA helicase II is required for single-stranded DNA binding. J. Bacteriol. 1999, 181, 2519-2526. [CrossRef] 
55. Yokota, H. Fluorescence microscopy for visualizing single-molecule protein dynamics. Biochim. Biophys. Acta Gen. Subj. 2020, 1864, 129362. [CrossRef] [PubMed]

56. Ali, J.A.; Maluf, N.K.; Lohman, T.M. An oligomeric form of E. coli UvrD is required for optimal helicase activity 1 1Edited by D. E. Draper. J. Mol. Biol. 1999, 293, 815-834. [CrossRef] [PubMed]

57. Maluf, N.K.; Ali, J.A.; Lohman, T.M. Kinetic Mechanism for Formation of the Active, Dimeric UvrD Helicase-DNA Complex. J. Biol. Chem. 2003, 278, 31930-31940. [CrossRef]

58. Yokota, H.; Han, Y.-W.; Allemand, J.-F.; Xi, X.G.; Bensimon, D.; Croquette, V.; Ito, Y.; Harada, Y. Single-molecule Visualization of Binding Modes of Helicase to DNA on PEGylated Surfaces. Chem. Lett. 2009, 38, 308-309. [CrossRef]

59. Runyon, G.T.; Wong, I.; Lohman, T.M. Overexpression, purification, DNA binding, and dimerization of the Escherichia coli uvrD gene product (Helicase II). Biochemistry 1993, 32, 602-612. [CrossRef]

60. Tomko, E.J.; Lohman, T.M. Modulation of Escherichia coli UvrD Single-Stranded DNA Translocation by DNA Base Composition. Biophys. J. 2017, 113, 1405-1415. [CrossRef]

61. Tomko, E.J.; Fischer, C.J.; Niedziela-Majka, A.; Lohman, T.M. A Nonuniform Stepping Mechanism for E. coli UvrD Monomer Translocation along Single-Stranded DNA. Mol. Cell 2007, 26, 335-347. [CrossRef] [PubMed]

62. Ali, J.A.; Lohman, T.M. Kinetic Measurement of the Step Size of DNA Unwinding by Escherichia coli UvrD Helicase. Science 1997, 275, 377-380. [CrossRef] [PubMed] 